\title{
UMA PINTURA DO DEUS AMOR: POÉTICA E RETÓRICA EM PROPÉRCIO 2.12
}

\author{
LyA SERIGNOLLI* \\ Universidade de São Paulo
}

\begin{abstract}
Resumo. Na elegia 2.12 de Propércio, o deus Amor é apresentado como obra admirável de um pintor e como veiculador da paixão erótica. Neste poema, a paixão erótica é comparada a uma guerra provocada pelo deus (militia amoris), motivando, de um lado, o lamento (que é uma das características determinantes do gênero elegíaco) e, de outro, despertando no poeta o desejo de escrever versos que agradam o deus. Neste artigo, meu objetivo é observar os aspectos retóricos e poéticos da elegia 2.12, considerando o tratamento dado à forma e às ações do Amor personificado. Inicialmente, irei investigar possíveis antecedentes desta elegia, tendo em vista a escolha dos lugares-comuns usados para compor a figura do deus. Em seguida, observarei aspectos do $\pi \dot{a} \theta$ oc amoroso como artifício retórico e impulso poético. Por fim, irei examinar as ligações da elegia 2.12 com outros poemas eróticos dos Livros 1 e 2 de Propércio, com enfoque na relação de interdependência entre as figurações do puer Amor como divindade tutelar da poesia e da puella elegíaca (Cíntia) como objeto das elegias de Propércio. Assim, tentarei demonstrar de que modo as características de Amor na elegia 2.12 podem evidenciar aspectos de um programa poético em que se incluem as elegias eróticas dos dois primeiros livros de Propércio.
\end{abstract}

Palavras-chave. Amor; Cupido; Eros; Propércio; imagem; poética; retórica.

D.O.I. 10.11606/issn.2358-3150.v19i1p82-109

Em textos gregos e latinos, o deus Amor (Eros/Cupido) É Frequentemente caracterizado como um menino alado, armado com arco e flechas. Sua beleza é descrita como perfeita e inigualável. Por seu caráter dual, de extrema doçura e crueldade implacável, recebeu o epíteto "doce-amargo"

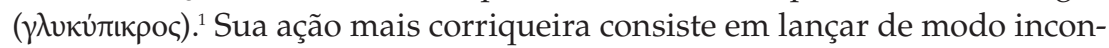
sequente setas envenenadas, subjugando suas vítimas, que, ao serem atin-

Doutoranda em Letras Clássicas pela Universidade de São Paulo, integrante do grupo de pesquisa Imagens da Antiguidade Clássica (CNPq). Sou grata à FAPESP pelo apoio financeiro para a realização desta pesquisa e a Paulo Martins e Evelina Meyer pela leitura de versões anteriores do texto e sugestões para o seu aperfeiçoamento.

* Artigo recebido em 05.ago.2015 e aceito para publicação em 31.out.2015.

${ }^{1}$ Safo, frag. 130 Voigt. Sobre Eros doce-amargo, cf. Calame 1999, 23-8; Serignolli 2013, 47-52; Ragusa 2009, 355; Carson 2009. 
gidas, passam a manifestar os sintomas da paixão erótica, ou rá日oc (páthos) amoroso. ${ }^{2}$ Entre vários significados, rá $\theta$ oc pode referir-se a: paixão, padecimento ou afeto. ${ }^{3}$ Mais especificamente, em retórica, o discurso que apela aos afetos pode despertar na audiência o prazer, a indignação ou a piedade, e tal artifício auxilia na persuasão. ${ }^{4}$ A paixão erótica, por sua vez, é descrita por autores gregos e latinos como um afeto que se instala nos órgãos vitais, gerando estados mentais que variam entre euforia, êxtase, insânia e furor, e provocando alterações fisiológicas, como palidez, palpitações, tremores e respiração ofegante. ${ }^{5}$

O Amor (Eros/Cupido), na sua forma personificada, apesar ser normalmente apresentado como um cruel inimigo, por ferir, dominar e escravizar suas vítimas, também é conhecido por beneficiar os que visita, emprestando seus dons como o êxtase, o vigor e a coragem. Favorecendo suas vítimas de um lado e de outro privando-as de razão, ele é conhecido por ludibriar até os deuses, induzindo-os cair sob o seu comando (nem mesmo Vênus escapa de sua ação ${ }^{6}$. Em suma, a paixão desencadeada por essa divindade é considerada ao mesmo tempo um benefício e uma punição.

Na elegia 2.12, o deus Amor é apresentado como obra admirável de um pintor e como veiculador do $\pi \dot{a} \theta$ oৎ amoroso. A paixão erótica, neste poema, é comparada a uma guerra provocada pelo deus (a militia amoris), motivando, de um lado, o lamento (que é uma das características determinantes do gênero elegíaco ${ }^{7}$ ) e, de outro, despertando no poeta o desejo de escrever versos que agradam o deus. Assim, Amor desempenha também, nesta elegia, o papel de divindade tutelar da poesia, tal como Apolo, Baco ou as Musas. Neste artigo, meu objetivo é observar os aspectos retóricos e poéticos da elegia 2.12, considerando o tratamento dado à forma e às ações do Amor personificado. Inicialmente, irei investigar possíveis antecedentes desta elegia, tendo em vista a escolha dos lugares-comuns usados para compor a figura do deus. Em seguida, observarei aspectos do $\pi \dot{a} \theta$ oc amoroso

2 LSJ, p. 1286: Pl., Phdr. 265b.

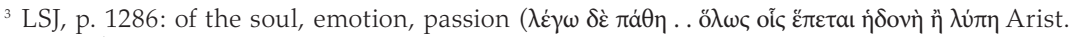

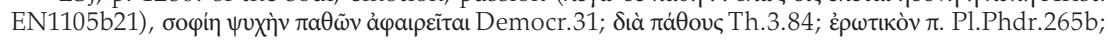

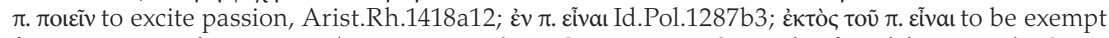

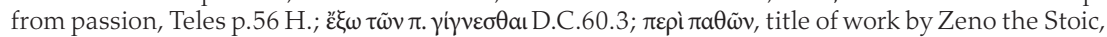

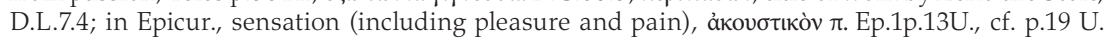

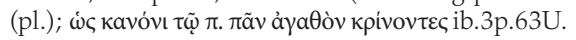

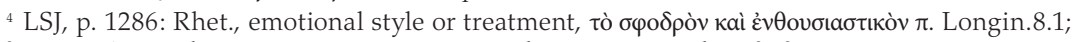

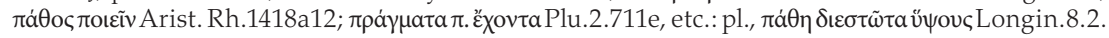

${ }^{5}$ Para os sintomas físicos da paixão erótica, cf. Calame (1999, 19-22), Serignolli $(2013,43)$.

${ }^{6}$ Cf. Ov., Met. 10.525-6: namque pharetratus dum dat puer oscula matri,/ inscius exstanti destrinxit harundine pectus.

${ }^{7}$ Querela ou querimônia: Hor., Ars Po. 75: versibus inpariter iunctis querimonia primum. 
como artifício retórico e impulso poético. Por fim, irei examinar as ligações da elegia 2.12 com outros poemas eróticos dos Livros 1 e 2 de Propércio, com enfoque na relação de interdependência entre as figurações do puer Amor como patrono da poesia e da puella (Cíntia) como objeto das elegias eróticas de Propércio. Assim, tentarei demonstrar de que modo a caracterização de Amor na elegia 2.12 pode evidenciar aspectos de um programa poético em que se incluem as elegias eróticas dos dois primeiros livros de Propércio.

Quanto à matéria, a elegia 2.12 pode ser dividida em duas partes. ${ }^{8} \mathrm{Na}$ primeira, são especificados os atributos de Amor na pintura: 1) menino, 2) alado e 3) armado com flechas. Na segunda parte, a ênfase é nos efeitos das ações do deus sobre o poeta, que expressa: 1) o lamento porque o deus alojou-se em seu peito, 2) o rá $\theta$ oc amoroso, evidenciado na condição de exaustão ocasionada pelo veneno das setas, e 3 ) o desejo de continuar escrevendo versos em louvor à puella elegíaca.

Quicumque ille fuit, puerum qui pinxit Amorem, nonne putas miras hunc habuisse manus? is primum vidit sine sensu vivere amantes, et levibus curis magna perire bona.

2.12.5 idem non frustra ventosas addidit alas, fecit et humano corde volare deum: scilicet alterna quoniam iactamur in unda, nostraque non ullis permanet aura locis. et merito hamatis manus est armata sagittis,

2.12.10 et pharetra ex umero Cnosia utroque iacet: ante ferit quoniam tuti quam cernimus hostem, nec quisquam ex illo vulnere sanus abit. in me tela manent, manet et puerilis imago: sed certe pennas perdidit ille suas;

2.12.15 evolat heu nostro quoniam de pectore nusquam, assiduusque meo sanguine bella gerit. quid tibi iucundumst siccis habitare medullis? si pudor est, alio traice tela, puer! intactos isto satius temptare veneno:

2.12.20 non ego, sed tenuis vapulat umbra mea. quam si perdideris, quis erit qui talia cantet, (haec mea Musa levis gloria magna tuast), qui caput et digitos et lumina nigra puellae et canat ut soleant molliter ire pedes?

Quem quer que tenha sido aquele que pintou o Amor menino, não crês que tivesse mãos admiráveis? Ele primeiro viu os amantes viverem sem juízo e grandes bens se perderem por fugazes paixões.

${ }^{8}$ Sobre a divisão dessa elegia, cf.: Fedeli (2005, 340), Nock (1929, 127), Enk (1929). 
2.12.5 Ele, com razão, acrescentou asas ligeiras e fez o deus voar pelo coração humano: é evidente, pois somos jogados por ondas alternadas, e a nossa brisa' não permanece em lugar algum. E, com razão, sua mão está armada com setas farpadas,

2.12.10 e uma aljava de Gnosso pende de seus ombros: porque fere antes que, em segurança, possamos discernir o inimigo, e ninguém se cura dessa ferida.

Em mim as setas permanecem, e permanece a imagem pueril: mas certamente ele perdeu suas asas;

2.12.15 ah, pois não voa de meu peito para lugar algum, e, assiduamente, trava batalhas em meu sangue.

Porque te agrada habitar em corações ressecados? Se há pudor, menino, atira em outro tuas setas! É melhor atingir os que estão intactos com este veneno:

2.12.20 não eu, mas minha tênue sombra está sendo açoitada. Se a destruíres, quem há de cantar tais temas (esta minha Musa leve é tua grande glória) e celebrar a face, os dedos, os olhos negros da menina e o modo como seus pés costumam mover-se suavemente?

\section{ANTECEDENTES}

Séculos antes de tornar-se lugar-comum na poesia latina, a descrição dos atributos de Eros era frequente em textos gregos. ${ }^{10}$ Por exemplo, na Teogonia, Eros é caracterizado como um dos deuses primordiais, cujo caráter paradoxal une extrema beleza física a uma tirania inigualável. ${ }^{11} \mathrm{Na}$ lírica arcaica, Safo, Arquíloco e Anacreonte enfatizaram os poderes dessa divindade como personificação da paixão erótica e veículo de afecções veementes. ${ }^{12}$ Eurípedes, em sua tragédia Hipólito, apresenta a ambivalente figura do Eros arqueiro, que é enviado por Afrodite como agente causador de uma paixão devastadora. ${ }^{13} \mathrm{Na}$ poesia latina, Amor aparece com frequência em comédias de Plauto e em Catulo, porém sua presença é mais marcante na poesia Augustana, em especial entre os poetas elegíacos (Propércio, Tibulo

\footnotetext{
${ }^{9}$ Considerando-se a metáfora da paixão erótica como tempestade marítima (causada pelo bater das asas de Eros), nostra aura pode referir-se à brisa marítima, que daria lugar à tormenta. Como o mar agitado, os amantes ficariam ao sabor das ondas, sem direção. Ver Fedeli (348) nosta aura: "il vento a noi favorevole". Richardson $(1977,246)$ : "aura: the breeze before which we sail (Butler). The shifting wind would tend to carry one off course and make the sailing dangerous and erratic." Cf.: Ovid, Am. 2.9.33: sic me saepe refert incerta Cupidinis aura (A instável brisa de Cupido amiúde me reconduz).

${ }^{10}$ Sobre a caracterização de Eros na poesia grega, cf. Calame 1999, Ragusa 2009, Carson 2009.

${ }^{11}$ Hes., Teog. 116-22.

${ }^{12}$ Safo, frag. 130 Voigt (Eros doce-amargo); Arch., frags. 191 e 193 W.; Anacr., frag. 413.

${ }^{13}$ Eur., Hipólito 525-ss.. Cf. também Sófocles, Ant. 781-801.
} 
e Ovídio), que o apresentam como personificação (e ao mesmo tempo veiculador) da paixão erótica e divindade tutelar da poesia. ${ }^{14}$

Quanto às fontes específicas da elegia 2.12, diversos autores citam o compêndio de Apolodoro, Perì theôn (Sobre os Deuses), do século II a.C. ${ }^{15}$ Embora desta obra tenham restado apenas fragmentos, fontes posteriores indicam sua relação com a elegia 2.12, especialmente no que se refere à ordem de apresentação dos lugares-comuns. ${ }^{16}$ A elegia 2.12 tem, ainda, ligação com textos filosóficos que discutem os atributos de Amor, por exemplo, o Simpósio de Platão, em que os participantes de um banquete discursam sobre as características de Eros. ${ }^{17}$ Há também evidências de que a comédia ateniense tenha sido outra fonte relevante. ${ }^{18}$ Mais especificamente, em fragmentos de comédias de Eubulo e de Aléxis (séc. IV a.C.), citados por Ateneu em Deipnosofistas, parte-se da descrição de uma obra de arte de um incógnito artífice para a discussão sobre os atributos de Eros..$^{19}$ Esses comediógrafos têm como fonte discussões filosóficas sobre os atributos do deus, porém eles, normalmente, contrariam as convenções: Aléxis diz ser por total ignorância que os pintores adicionam asas a Eros, pois quem possui asas são os amantes, e não o deus. ${ }^{20}$ Em outra passagem, ele diz que os pintores, escultores e quem quer que tenha concebido uma imagem de Eros são ignorantes de sua real natureza, pois ele não é masculino e nem feminino, não é deus e nem homem, não é sábio e nem tolo; mas possui todas a qualidades, e por trás de uma só forma escondem-se diversas naturezas. ${ }^{21}$

Eubulo também refere-se a um incógnito inventor, dizendo que quem quer que tenha sido o primeiro a modelar ( ( $\gamma \rho \alpha \dot{\varphi} \varphi)$ Eros com asas é ignorante de sua natureza, porque ele é não é suave e nem fácil, mas um mestre tenaz e severo. ${ }^{22}$ Propércio, por sua vez, como se nota no primeiro verso da elegia 2.12, tampouco especifica quem seria o inventor da pintura, adotando o pronome indefinido quicumque para designá-lo. Nessa passagem, ao omitir o nome do autor da pintura, Propércio

${ }^{14}$ Plauto, Bac. 114-6: \{LYD.\} Quid huc? quis istic habet?/ \{PIST.\} Amor, Voluptas, Venus, Venustas, Gaudium,/Iocus, Lúdus, Sermo, Suavisaviatio. Cat., Carm. 3.1-5, 45.8-17; 36.3.

${ }^{15}$ Sobre os antecedentes da elegia 2.12, cf. Richardson (1977, 245); Nock (1929); Long (1978); Fedeli (2005).

${ }^{16}$ A principal evidência dessa relação é o Compêndio de Teologia Grega de Cornuto, texto que, embora posterior (século I d.C.) à elegia de Propércio, provavelmente teve com fonte o compêndio de Apolodoro. Cf. Lang 1881, 47-8.

${ }^{17}$ Platão, Simp. 194e-196c.

${ }^{18}$ Cf. Laurens 1988, 258-9.

${ }^{19}$ Ateneu, Deipnosofistas. Cf. S. P. Peppink (1939).

${ }^{20}$ Fragmento de Apocoptomenos, em: Athen., Deip. (epitome) 2,2.104.7.

${ }^{21}$ Fragmento de Fedro em Athen., Deip. (epitome) 2,2.103.35.

${ }^{22}$ Em fragmento de Campylion, em: Athen., Deip. (epitome) 2,2.104.11-ss.. 
está utilizando a tópica do rival, que deve ficar incógnito por tratar-se de alguém cujas particularidades não valeria a pena mencionar. ${ }^{23}$ Propércio, porém, surpreende o leitor ao aprovar as escolhas do primus inventor, invertendo a tópica utilizada pelos comediógrafos gregos, em que é convencional a execração do artífice. A sinédoque mirae manus (mãos admiráveis), no segundo verso, é um elogio ao engenho do artífice, ${ }^{24}$ e lembra essa passagem

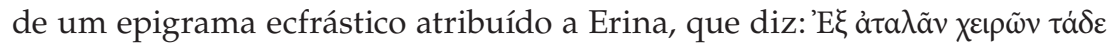

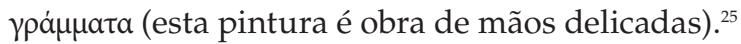

Nota-se, assim, que o elogio prevalece ao longo da primeira parte da elegia 2.12, pois o poeta não só reconhece o engenho do artífice que concebeu a pintura do puer Amor, mas também convida o leitor a fazê-lo (nonne putas). Propércio ressalta como parece ser adequada a figuração de Eros nessa pintura que reflete o comportamento dos amantes sob o efeito da paixão. Contudo, o poema vai adquirindo um tom mais dramático à medida que Propércio, assumindo o papel de vítima, passa a evidenciar os efeitos das ações do deus sobre sua persona poética. Cada um dos atributos de Amor apresentados na primeira parte correspondem a determinados sintomas do $\pi \dot{a} \theta$ oc amoroso explicitados na segunda parte.

Quanto à caracterização de Amor como causador de $\pi \dot{a} \theta$ oc, a elegia 2.12 tem forte ligação com os epigramas eróticos helenísticos, especialmente os de Meleagro, que faz uso intenso de imagens e evidencia os efeitos do amor por meio da descrição de Eros. ${ }^{26}$ Gutzwiller observa que "a representação da variedade de afetos dos amantes na breve forma epigramática abre caminho para o desenvolvimento da elegia erótica romana, com sua complexa gama de matizes afetivas". ${ }^{27} \mathrm{Na}$ elegia 2.12 de Propércio, nota-se a dramaticidade epigramática nas expressões de inquietação, lamento e indignação do poeta perante às ações do deus.

${ }^{23}$ Fedeli $(2005,341-2)$. Para outros exemplos da tópica do rival, cf. Tib., 1.3.81; Ov., Am. 3.2.21; Hor., Epod. 15.17-18. O uso de ille após quicumque, no primeiro verso, pode reforçar a ideia de desdém pelo rival. Ille, OLD 4c: (with a contemptuous or derogatory connotation) that vaunted, the so-called, the infamous.

${ }^{24}$ Sobre essa tópica em epigramas ecfrásticos, cf.: Mannlein-Robert 2007, 251-71.

${ }^{25}$ Erina, A. P. 6.352.1.

${ }^{26}$ Na poesia epigramática, estão entre os principais antecedentes da elegia 2.12: Meleagro, $A$. $P$. 5.176, 177, 178, 179, 198, 212 e 214. Possidipo, A. P. 12.45. Árquias, A. P. 5.58 e 98; Asclepíades, $A$. P. 12.46. Mosco, A. P. 9.449 (Eros Fugitivo). No poema conhecido como Eros Fugitivo (A. P. 9.449), Mosco apresenta uma descrição de Eros com os mesmos atributos que Amor na elegia 2.12 (um menino alado portando flechas e aljava), porém mais detalhada, mencionando a tocha, os cabelos encaracolados, os olhos de fogo, a voz de mel e o beijo envenenado. Sobre a caracterização de Eros em epigramas eróticos helenísticos, cf. Syndikus (2006, 269); K. J. Gutzwiller (2007, 329), Garrison (1978).

${ }^{27}$ Gutzwiller (2007, 327). 
Nos versos 7-8, a tópica da tempestade marítima provocada por Eros (alterna ... iactamur in unda ... non ullis permanet aura locis) é uma metáfora para a instabilidade dos afetos dos enamorados, e lembra estes versos de Meleagro:

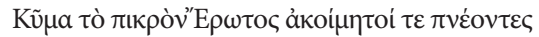

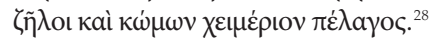

Ondas amargas de Eros, inquietos e ventosos ciúmes e mar tempestuoso de pândegas. ${ }^{29}$

No verso 15 (evolat heu ... de pectore nusquam), Propércio usa os motivos da permanência contínua do deus no coração e do eterno tormento do amor. ${ }^{30}$ Essa expressão de lamento pode ser comparada a uma apóstrofe endereçada aos Erotes neste epigrama de Meleagro:

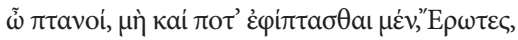

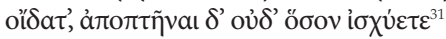

$$
\begin{aligned}
& \text { Ó alados, só sabeis voar até mim, Amores, } \\
& \text { e não vos esforçais para voar mais longe. }{ }^{32}
\end{aligned}
$$

No verso 18 (si pudor est, alio traice tela, puer!), invertendo uma tópica usada em hinos sacros para invocar a assistência de uma divindade, Propércio repudia a ação do deus, ordenando que ele se afaste. ${ }^{33}$ Essa passagem, que exprime a impaciência do poeta em face aos ataques de Cupido, assemelha-se a estes versos de Meleagro:

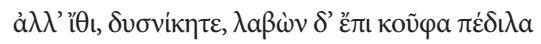

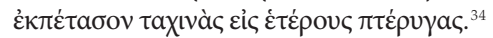

Mas vai, implacável! Calça as reluzentes sandálias e voa com as tuas asas lestas para outros. ${ }^{35}$

Propércio não apenas coloca diante dos olhos do leitor uma imagem da pintura de Cupido com as tonalidades marcantes da poesia epigramática,

\footnotetext{
${ }^{28}$ Meleagro, A.P. 5.190.1-2.

${ }^{29}$ Tradução de F. V. Amaral (2009).

${ }^{30}$ Para a tópica da permanência contínua de Eros no coração, ver também Asclepíades, A.P. 12.147.

${ }^{31}$ Meleagro, A. P. 5.212.5-6.

${ }^{32}$ Tradução de F. V. Amaral (2009).

${ }^{33}$ Horácio também usa esta tópica invertida em Carm. 4.1.7-12. Cf.: Fedeli (2005, 353).

${ }^{34}$ Meleagro, A. P. 5.179.9-10.

${ }^{35}$ Tradução de Amaral 2009.
} 
mas também sugere um embate entre o poeta e o deus. Com a habilidade de um Aquiles, Amor abate suas vítimas antes que elas possam notar (ante ferit ... quam cernimus hostem). As referências de lugar: humano corde, nostro pectore, meo sanguine e siccis medullis indicam que o conflito se dá no interior do corpo. Como sugere Calame, Eros primeiro se aloja em partes do corpo consideradas como sede da vida e dos afetos, antes que o seu poder seja completamente incorporado por alguém capaz de expressá-lo em primeira pessoa. ${ }^{36}$ Entre os gregos, os termos mais usados em referência ao lugar onde Eros se

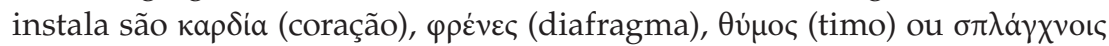
(órgãos vitais), que correspondem aos termos cor (coração), medulla (medula), sanguis (sangue) e pectus (peito) usados na elegia de Propércio. ${ }^{37}$

Assim, Propércio combina elementos da fisiologia erótica com a tópica militia amoris, estabelecendo o corpo como um cenário em que o Amor personificado provoca uma guerra de consequências desastrosas. O poeta é obrigado a travar uma luta desigual contra o deus, que circula em suas veias (meo sanguine bella gerit) e se aloja em seu peito, de onde se recusa a sair (euolat heu nostro ... de pectore nusquam).$^{38}$ Como sugere Barber, nesse poema há uma graciosa confusão de imagens, pois Amor é ao mesmo tempo o arqueiro que atinge de fora para dentro e o atormentador que habita no coração do amante. ${ }^{39}$

Nas Tusculanas, Cícero define o amor como um afeto cuja frivolidade (leuitas) é tamanha, que não há nada a que possa ser comparado. ${ }^{40}$ Para explicar o amor como afeto, Cícero cita diversas passagens da poesia, entre elas, uma de um poeta cômico que refere-se a Amor como o maior entre os deuses, pois ele tem o poder de determinar quem irá enlouquecer e quem terá sanidade, quem irá adoecer e quem será curado. ${ }^{41}$ Cícero ironiza o sta-

${ }^{36}$ Calame 1999, 19-33.

${ }^{37}$ De acordo com Calame (1999, 19), os termos que compõem o amplo repertório da "fisiologia afetiva" no mundo grego nem sempre são facilmente traduzíveis para a nossa nomenclatura, que

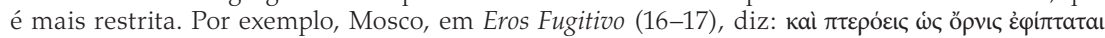

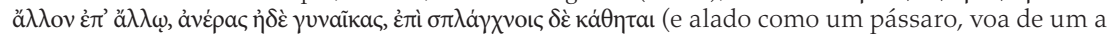

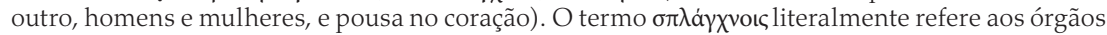
vitais, mas tendemos a traduzir como coração. Para o uso desses termos na poesia grega, cf.:

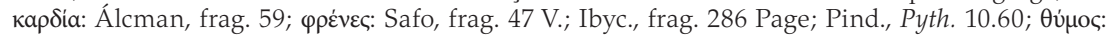
Alceu, frag. 283.3f.; Safo, frag. 1 V..

${ }^{38}$ Fedeli $(2005,354)$.

${ }^{39}$ Barber $(1996,210)$.

${ }^{40}$ Cic., Tusc.: totus vero iste, qui volgo appellatur amor - nec hercule invenio, quo nomine alio possit appellari - , tantae levitatis est, ut nihil videam quod putem conferendum.

${ }^{41}$ Cic., Tusc. 4.68.9-12: quem Caecilius "deum qui non summum putet, aut stultum aut rerum esse imperitum" existumat, "Cui ín manu sit, quem ésse dementém velit, Quem sápere, quem sanári, quem in morbum ínici". Sobre essa passagem, cf. Graver 2002, 178: "referência a uma comédia não identificada. Comparar com Eurípides, fr. 169 Nauck". 
tus de divindade atribuído a Amor pelos poetas, por ser ele o causador dos maiores escândalos e leviandades, ${ }^{42}$ e adverte que o furor do amor (furor amoris) é a mais veemente entre as perturbações do ânimo:

maxume autem admonendus <est $>$, quantus sit furor amoris. omnibus enim ex animi perturbationibus est profecto nulla vehementior. ${ }^{43}$

Porém, deve-se sobretudo advertir quão grande é o furor do amor; pois de todas as perturbações do ânimo, seguramente, nenhuma é mais veemente.

Cicero explica que afetos veementes acarretam estados de inquietude e excitação do ânimo, que, quando tornam-se crônicos, é como se tomassem assento nas veias e na medula, desencadeando doenças, debilidades e indisposições. ${ }^{44}$ Do mesmo modo, na elegia 2.12, os afetos veementes veiculados por Amor podem ser comparados a uma afecção que se instala no corpo em decorrência dos ferimentos causados no embate contra o deus. As setas que atravessam os ossos causam uma ferida (vulnus), carregando para dentro do corpo o veneno, que se espalha pela corrente sanguínea e resseca as entranhas (siccis medullis)..$^{45}$

No De Inventione, Cícero define o amor como uma afecção do ânimo (animi affectionis) que pode levar alguém a agir por impulso:

Causa tribuitur in inpulsionem et in ratiocinationem. inpulsio est, quae sine cogitatione per quandam affectionem animi facere aliquid hortatur, ut amor, iracundia, aegritudo, vinolentia et omnino omnia, in quibus animus ita videtur affectus fuisse, ut rem perspicere cum consilio et cura non potuerit et id, quod fecit, impetu quodam animi potius quam cogitatione fecerit. ${ }^{46}$

A causa de um ato é atribuída ao impulso ou à premeditação. O impulso é aquilo que instiga alguém a fazer algo sem pensar, por causa de alguma afecção do ânimo, como o amor, a ira, a aflição, embriaguez e, assim, todo estado em que o ânimo pareça ter sido afetado, de modo que não se consiga observar os atos com cuidado e prudência e aquilo que se fez tenha sido movido por um ímpeto do ânimo e não pela reflexão.

A força do amor (vis amoris) é incluída entre os loci de amplificação retórica que podem ser empregados pela acusação como motivadores de determinado crime:

${ }^{42}$ Cic., Tusc: 4.68.15-4.69.1: o praeclaram emendatricem vitae poëticam, quae amorem flagitii et levitatis auctorem in concilio deorum conlocandum putet!

${ }^{43}$ Cic., Tusc. 4.75.

${ }^{44}$ Cic., Tusc. 4.23-4.

${ }_{45}$ Também em Ov., Met. 1.473: traiecta per ossa medullas.

${ }^{46}$ Cic., De Inv. 2.17. 
Hic locus sicut aliquod fundamentum est huius constitutionis. nam nihil factum esse cuiquam probatur, nisi aliquid, quare factum sit, ostenditur. Ergo accusator, cum inpulsione aliquid factum esse dicet, illum impetum et quandam commotionem animi affectionemque verbis et sententiis amplificare debebit et ostendere, quanta vis sit amoris, quanta animi perturbatio ex iracundia fiat aut ex aliqua causa earum, qua inpulsum aliquem id fecisse dicet. hic et exemplorum commemoratione, qui simili inpulsu aliquid commiserint, et similitudinum conlatione et ipsius animi affectionis explicatione curandum est, ut non mirum videatur, si quod ad facinus tali perturbatione commotus animus accesserit. ${ }^{47}$

Este tópos pode ser chamado de fundamento ou estado da questão, pois nenhum fato pode ser provado sem que se apresente um motivo pelo qual o ato tenha sido praticado. Portanto, quando a acusação diz que algo foi feito por impulso, ela deverá necessariamente amplificar com palavras e expressões esse ímpeto, particularmente a agitação ou comoção do ânimo, e mostrar, quão grande força é o amor, quanta perturbação mental decorre da ira, ou de quaisquer outras causas pelas quais ele argumente que o acusado tenha sido levado a agir. Deve-se cuidar para que não pareça estranho que tal crime tenha sido cometido por alguém com o ânimo tomado por tal impulso. Isso pode ser feito mencionando-se exemplos daqueles que fizeram algo movidos por semelhante impulso, e traçando-se paralelos e explicando-se a natureza de tal distúrbio mental.

Na elegia 2.3ob, Propércio proclama fidelidade a Cíntia, defendendo o direito de permanecer ao seu lado, a despeito de críticas e acusações. $\mathrm{O}$ vocabulário e os argumentos usados nesse poema aproximam-se do discurso judiciário. Palavras como lex, crimen e culpa são adaptadas para o âmbito dos gêneros poéticos, sendo antiquae leges uma referência às preceptivas da poesia elevada, e crimen amoris à prática da poesia erótica. ${ }^{48} \mathrm{O}$ poeta estaria violando as leis antigas ao dar preferência a Cíntia (como metáfora para a elegia erótica). Própercio, no entanto, exime-se de culpa, dizendo que se alguém cometeu algum crime, não foi ele, mas Amor:

una contentum pudeat me vivere amica?

hoc si crimen erit, crimen Amoris erit:

2.30b.25 mi nemo obiciat. libeat tibi, Cynthia, mecum

rorida muscosis antra tenere iugis. ${ }^{49}$

Devo envergonhar-me de viver contente com minha amiga?

Se isto for crime, terá sido Amor quem o cometeu:

2.30b.25 que ninguém me censure. Que te agrade, Cíntia, ficar comigo em uma gruta orvalhada nos montes cobertos de musgo.

${ }^{47}$ Cic., De Inv. 2.19-20.

${ }^{48}$ Cf. antiquae leges, Prop., 2.30b.15. Sobre o uso da linguagem jurídica neste poema, cf. Cairns (1971, 210); Gunther (2006, 212); Martins $(2009,73)$. Para a tópica do amor como crime em epigramas, cf. Meleagro, A. P. 12.147.

${ }^{49}$ Prop., 2.30b.23-6.

Let. Cláss., São Paulo, v.19, n.1, p. 82-109, 2015 
Usando a tópica omnia vincit Amor, ${ }^{50}$ Propércio alega ser impossível lutar contra os desígnios do deus, colocando-se assim no papel de vítima:

quod si nemo exstat qui vicerit Alitis arma, communis culpae cur reus unus agor? ${ }^{51}$

Pois se não existe ninguém que tenha vencido as armas do Alado, por que somente eu sou acusado como único réu de uma culpa comum?

A partir dos exemplos acima, nota-se que o amor, tanto em textos filosóficos e retóricos como na poesia, é comparado à uma afecção do corpo e da mente, que se instala nas entranhas como um fervor e atinge os órgãos do intelecto, gerando furor e inquietação. Este afeto, por seu poder penetrante, é apontado como causa de ações movidas por impulsos que ultrapassam os limites da razão. ${ }^{52}$ Nas elegias de Propércio, o Amor personificado não é simplesmente o veiculador de afetos veementes que provocam uma ferida incurável, mas é também a força que impulsiona o poeta a escrever versos em louvor a Cíntia, justificando sua escolha pela poesia erótica.

\section{RETÓRICA}

Boa parte dos estudos sobre a elegia 2.12 faz menção à sua estrutura retórica. Alguns autores identificam na elegia 2.12 as características da écfrase..$^{53}$ Nos Progymnasmata, Nicolau refere-se à écfrase aplicada à descrição de estátuas e pinturas, sugerindo que um dos recursos para obtenção de

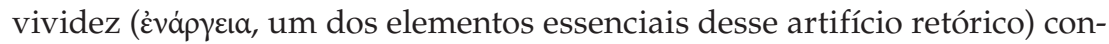
siste em explicar as razões pelas quais o objeto possui determinada forma ou expressão. ${ }^{54}$ Nock chega a afirmar que a elegia 2.12 é um típico exercício em verso, em que elementos da lenda fazem paralelos com as experiências da persona poética. ${ }^{55}$ Mais especificamente, a maioria dos estudos sobre

${ }^{50}$ Para a tópica omnia vincit Amor na elegia romana, cf. Serignolli 2013, 135-43.

${ }^{51}$ Prop. 2.30b.31-32.

52 Sobre o poder de Eros de anular a razão, cf. Calame 1999, 19.

${ }^{53}$ Sobre a elegia 2.12 como écfrase, cf. Martins 2013, 85; Laurens 1988, 256.

${ }^{54}$ Cf. Kennedy $(2003,167)$, Nicolau 69: "Whenever we compose ecphrases, and especially descriptions of statues or pictures or anything of that sort, we should try to add an account of this or that impression made by the painter or by the molded form; for example, that he painted the figure as angry for this reason, or as pleased; or we shall mention some other emotion as occurring because of the history of what is being described. Similarly in other cases also, explanations contribute to vividness.".

${ }^{55}$ Nock $(1929,127)$. 
esta elegia indicam sua relação com um exercício retórico mencionado por Quintiliano nas Instituições Oratórias, em que a caracterização de Cupido é um dos temas sugeridos para o desenvolvimento de causas conjecturais. ${ }^{56}$ Nesse exercício, comparado a uma espécie de chria $^{57}$ (anedota ou breve narrativa sobre determinado personagem), os alunos deveriam apresentar indícios que justificassem ou refutassem a convenção sobre os lugares-comuns pertinentes à caracterização de Cupido:

Solebant praeceptores mei neque inutili et nobis etiam iucundo genere exercitationis praeparare nos coniecturalibus causis cum quaerere atque exequi iuberent "cur armata apud Lacedaemonios Venus" et "quid ita crederetur Cupido puer atque uolucer et sagittis ac face armatus" et similia, in quibus scrutabamur uoluntatem, cuius in controuersiis frequens quaestio est: quod genus chriae uideri potest. ${ }^{58}$

Os meus preceptores costumavam preparar-nos para causas conjecturais com uma espécie de exercício, útil e até mesmo agradável, em que ordenavam que indagássemos e desenvolvêssemos questões, como: "Por que Vênus em Esparta veste uma armadura?" e "Por que acreditava-se que Cupido fosse um menino alado e armado com setas e tocha?" e outras semelhantes, em que perscrutávamos a intenção, questão que é frequente em controvérsias: este exercício pode assemelhar-se a uma espécie de chria.

Como observamos acima, quatro atributos do deus são sugeridos como tópicos para o exercício, que consistia em indagar por que acreditavase que Cupido é: (1) um menino (puer), (2) alado (volucer), (3) armado com setas (sagittae) e (4) tochas (fax). Propércio, por sua vez, se atém a três desses aspectos, descrevendo Amor simplesmente como um menino alado e armado com setas. Segundo observa Nock, Propércio, omitindo outros detalhes, evita que o poema torne-se muito longo, além de obter uma sequência de três analogias, uma estrutura encontrada em várias outras de suas elegias. ${ }^{59}$

Long chama a atenção para a nota de surpresa ou indignação em perguntas iniciadas com a expressão quid ita, e sugere que a sua presença na questão proposta pelo professor de Quintiliano pode indicar que esperava-se que os alunos respondessem o exercício desenvolvendo uma tese à maneira dos comediógrafos, contradizendo as convenções. ${ }^{60}$ Para Long, o ponto de partida de Propércio não é a pintura, mas a retórica. Desse

${ }^{56}$ Sobre a relação deste poema com um exercício retórico, cf. Fedeli $(2005,341)$, Long (1978, 142), Nock (1929, 126), Wyke (2002, 63), Laurens (1988, 256), Martins (2013, 83). Cairns (2010, 75) usa o termo grego катабкєuń para referir-se a este poema como exercício retórico.

${ }^{57}$ Sobre chria como exercício retórico, Kennedy $(2003,97)$.

${ }^{58}$ Quint., Inst. Or. 2.4.26.

${ }^{59}$ Nock $(1929,127)$. Para outros exemplos de três sequências de analogias em Propércio, cf. Prop. 1.3, 2.6 e 3.2 .

${ }^{60}$ Long 1978, 141-2.

Let. Cláss., São Paulo, v. 19, n. 1, p. 82-109, 2015 
modo, a primeira parte da elegia seria como um divertido e surpreendente "falso início", em que o poeta ironicamente justifica a introdução de cada elemento da pintura, utilizando expressões que demandam aprovação, como non frusta, merito e scilicet; enquanto a segunda parte seria como uma reviravolta, em que confirmam-se os argumentos costumeiros dos alunos de retórica, baseados na experiência pessoal. Por exemplo, Propércio, que antes havia justificado a presença das asas na pintura, passa a questioná-la, sugerindo ironicamente que Amor as perdeu, pois não quer sair mais de seu peito, onde trava batalhas infindáveis. Com a vivacidade epigramática e o humor dos comediógrafos gregos, Propércio dá forma ao seu poema, seguindo uma estrutura argumentativa próxima daquela sugerida no exercício retórico citado por Quintiliano.

\section{POÉTICA}

A elegia 2.12 foi discutida por vários autores quanto à sua importância em questões programáticas e de divisão dos livros de Propércio. Paulo Martins, em recente estudo, observa a posição estratégica desta elegia na coleção de poemas eróticos de Propércio, observando-a como écfrase e digressão. Como écfrase, por meio da descrição da pintura, ela anteciparia os argumentos a serem desenvolvidos e confirmados nas elegias seguintes. ${ }^{61}$ Como digressão, ela sintetizaria elementos essenciais da poética dos livros anteriores em um argumento maior, o amor. Desse modo, para Paulo Martins, esta elegia, reunindo estas características, pode ser observada como poema de abertura de um novo livro, em que a temática amorosa passa a ser vista sob outra perspectiva, menos focada no amor por Cíntia e com maior ênfase nos efeitos do amor como afecção. Maria Wyke, por sua vez, não reconhece este poema como introdutório de um novo livro, porém enfatiza sua importância na narrativa poética que liga as elegias de Propércio. ${ }^{62} \mathrm{~A}$ meu ver, há fortes indícios de que este poema seja o primeiro de um novo livro, porém não é meu objetivo ponderar esta questão, que já foi amplamente discutida por diversos autores. ${ }^{63}$ Como propus inicialmente, meu objetivo é observar os elementos da caracterização de Amor que delimitam aspectos de um programa poético em que se incluem as elegias eróticas dos Livros 1 e 2 de Propércio, tendo em vista particularmente a relação de

\footnotetext{
${ }^{61}$ Martins 2013, 77.

${ }^{62}$ Wyke 1987, 59-61.

${ }_{63}$ Martins 2013, 72-88; Lachman 1816; Skutsch 1975; Lyne 1998; Goold 1990; Murgia 2000.
} 
interdependência entre as figurações do puer Amor como patrono da poesia e da puella (Cíntia) como objeto das elegias de Propércio. ${ }^{64}$

Nos dois dísticos finais da elegia 2.12, Propércio sugere que, se for destruído, não haverá outro poeta capaz de celebrar os atributos da puella.${ }^{65}$ Cíntia é a protegida do puer Amor, e os versos suaves dedicados a ela são motivo de grande glória para o deus (haec mea Musa levis gloria magna tuast). Maria Wyke observa como os diversos aspectos do gênero elegíaco se entrecruzam nas figurações do puer Amor e da puella elegíaca na elegia 2.12. ${ }^{66}$ De acordo Wyke, pode-se observar dois artífices neste poema, o pintor e o poeta, de cuja arte resultam dois artefatos eróticos, respectivamente, os retratos do puer na pintura (pingere Amorem) e da puella na poesia (canere puellam). Puer Amor e puella elegíaca ligam-se pelos adjetivos levis e magnus (vv. 4 e 22), que referemse ao modo de composição de tais artefatos, evidenciando a tópica da leveza calimaqueana em contraposição à elevação da épica. A coesão desses dois esboços, segundo Wyke, encoraja o leitor a observar que a transição de puer para puella é aquela de uma obra de arte visual para outra verbal, dois modos de representação que demarcam a arena do discurso erótico de Propércio.

Propércio inicia seu primeiro livro de elegias referindo-se à capacidade de cativar da amada e à submissão do poeta às imposições de Amor, que o mantém sob o seu jugo, não permitindo que ele desvie os olhos de sua única e insubstituível amada, a quem ele fielmente dedica versos de amor. Assim sendo, Amor tem papel fundamental na determinação do objeto da poesia. Como guardião $\left(\right.$ custos $\left.^{67}\right)$ de Cíntia, ele garante que Propércio só tenha olhos para ela, mantendo-a como heroína singular de suas elegias:

Cynthia prima suis miserum me cepit ocellis,

contactum nullis ante cupidinibus.

tum mihi constantis deiecit lumina fastus

et caput impositis pressit Amor pedibus ${ }^{68}$

Cíntia foi a primeira a capturar-me com seus olhinhos; pobre de mim, nunca antes atingido pelos Cupidos. ${ }^{69}$ Amor, então, ordenou que eu abaixasse o olhar arrogante e pressionou minha cabeça, mantendo-a sob os seus pés.

${ }^{64}$ Sobre as características de Cíntia como marcadores programáticos, cf. Wyke 2002, Martins 2016.

${ }^{65}$ Para comparação dos versos finais com antecedentes gregos, cf. Fedeli 2005, 352.

${ }^{66}$ Wyke 2002, 66.

${ }^{67}$ Para Amor como custos, cf. Serignolli 2013, 131-3.

${ }^{68}$ Prop., 1.1.4.

${ }^{69}$ Propércio utiliza o termo cupidines, que pode ser interpretado como "desejos", mas também creio ser possível uma tradução como "Cupidos", com letra maiúscula, referindo-se às personificações. Estou utilizando a edição de Goold, que traz o ablativo cupidinibus em minúscula, não referindo-se, portanto, à personificação. A escolha por minúscula, porém, parte do editor, que eu optei por não seguir em minha tradução. 
Desse modo, o poeta constrói sua persona como poeta-amator e a persona da puella como amada-poesia.

Na primeira elegia do Livro 2, Propércio enfatiza o papel da docta puella na composição poética, apontando-a como fonte de seu engenho: ingenium nobis ipsa puella facit ${ }^{70}$ (minha amada produz o meu engenho). ${ }^{71}$ No poema seguinte, Amor é responsável por gerar ilusões quanto à figura da amada, fazendo com que ela pareça comparável às mais exuberantes deusas, impedindo assim que o poeta se liberte do seruitium amoris. ${ }^{72} \mathrm{O}$ jogo de dominação do olhar e pelo olhar é um principais artifícios do deus, que cria ilusões para salientar ainda mais a beleza de Cíntia:

Liber eram et vacuo meditabar vivere lecto;

at me composita pace fefellit Amor.

cur haec in terris facies humana moratur?

Iuppiter, ignosco pristina furta tua. ${ }^{73}$

Eu era livre e planejava jamais dividir um leito; porém, simulando a paz, Amor me enganou. Como pode tal beleza habitar entre os mortais? Júpiter, eu relevo os teus furtivos amores do passado.

Ludibriado por Amor, o poeta só tem olhos para essa mulher de longas comas esvoaçantes, bela e elegante com suas vestes de Cós: sua beleza ultrapassa a das deusas ${ }^{74}$; ela é uma segunda Helena ${ }^{75}$; ela é quem o move para escrever suas longas Ilíadas. ${ }^{76}$ Como sugere Stahl, "Cíntia é a encarnação de tudo aquilo que o amor pode fazer pelo poeta". ${ }^{77}$ Enfim, o poeta realizará os combates de Vênus e Cupido, até heroicamente obter a fama e a glória almejadas. ${ }^{78}$ Como diz Newman, o poeta elegíaco, no amor, "exerce todas as grandes virtudes da vida pública romana no fórum e no campo de batalha: fides, constantia, grauitas e até mesmo vigilantia". ${ }^{79}$ Porém, como notamos na elegia 2.12, o poeta, ironicamente, recusa-se a morrer em campo de batalha, suplicando ao deus para ser poupado, para que assim possa continuar escrevendo versos de amor à mulher amada.

${ }^{70}$ Prop. 2.1.3.

${ }^{71}$ Sobre o papel da puella elegíaca na composição poética, cf. Wyke 2002, 49; Martins 2013, 82-3; Martins 2016, 208, 222.

${ }^{72}$ Para a tópica servitium amoris, cf. Serignolli 2013, 130-43.

${ }^{73}$ Prop., 2.2.1-4.

${ }^{74}$ Cf. Prop., 2.2.13. Sobre a beleza de Cíntia como tópica elegíaca, Martins 2016, 209-11.

${ }^{75}$ Cf. Prop., 2.3.32. Sobre Cíntia como Helena, cf. Martins 2017, no prelo.

${ }^{76}$ Cf. Prop., 2.1.14.

77 Stahl (1985).

${ }^{78}$ Prop., 2.1.47.

${ }^{79}$ Newman $(1997,393)$. 
A partir da elegia 2.10, evidencia-se uma modificação no tratamento da matéria erótica, que, embora permaneça central ao longo de todo o livro 2, adquire novas perspectivas, que já foram discutidas por autores, como Paulo Martins, Lyne, Tatum e Maria Wyke. ${ }^{80}$ A elegia 2.10 é um raro exemplo de recusatio invertida, em que Propércio simula uma recusa da elegia em favor da épica. Nos versos iniciais, ele sugere a expectativa de ascender ao Hélicon, o que significaria elevar a sua poesia ao nível da épica, abandonando os temas eróticos da juventude e dando preferência àqueles mais adequados ao seu êthos de poeta maduro: aetas prima canat Veneres, extrema tumultus $^{81}$ (Na juventude cantam-se os Amores, na maturidade o conflito) ${ }^{82}$ No entanto, Amor aparece ao final do poema à margem do rio Permesso e ali banha os poemas de Propércio:

nondum etiam Ascraeos norunt mea carmina fontes, sed modo Permessi flumine lavit Amor. ${ }^{83}$

Os meus poemas ainda não conhecem as fontes de Ascra, mas o Amor banhou-os tão somente nas águas de Permesso.

Assim, prorroga-se o momento de sua ascensão, com a permanência do poeta no sopé do Monte Hélicon, onde ele continua cantando os temas mais humildes e tênues de suas elegias.

A imagem resplandecente da puella (que no decorrer do Livro 2 passa a se desgastar) é reduzida a cinzas na epigramática elegia 2.11 (cinis hic docta puella fuit ${ }^{84}$ - esta cinza foi uma douta menina), considerada por vários autores como o encerramento de um segundo livro de elegias.

A elegia 2.12 marca uma transição, seja para a segunda parte do Livro 2, seja como poema de abertura de um terceiro livro. ${ }^{85}$ Como havíamos observado anteriormente, nessa elegia, como propõe Paulo Martins, a matéria erótica é apresentada com uma preocupação maior com os afetos dos

${ }^{80}$ Martins 2013; Lyne 1988; Tatum 2010; Wyke 2002, 51-9.

${ }^{81}$ Prop., 2.10.7.

${ }^{82}$ De acordo com Tatum (2000:399): "A iniciação do poeta pelas Musas no monte Helicon, que se deve à apropriação de Calímaco da ideia de Hesíodo, é uma convenção literária alexandrina fundamental, assim com o (também antigo) emprego das fontes e rios como símbolos de inspiração poética".

${ }^{83}$ Prop., 2.10.25-6. Esses versos reverberam a passagem da Teogonia em que as Musas banham-se no Permesso antes da ascensão ao Hélicon, com a diferença que nesta elegia os poemas de Propércio é que são lavados por Amor antes da pretensa ascensão. Cf. também, em Virg., Ecl. 6.64-ss., a imagem de Gallo no rio Permesso.

${ }^{84}$ Prop., 2.11.6.

${ }^{85}$ Sobre a elegia 2.12 como poema de transição ou poema de abertura de um novo livro, Lyne (1998), Tatum (2000), Martins (2013). 
amantes (e do poeta) do que com Cíntia especificamente. ${ }^{86}$ Por outro lado, no final do poema, Propércio atribui novamente um corpo à puella elegíaca, mencionando sua face (caput), seus dedos (digiti), seus olhos negros (lumina nigra) e a delicadeza de seu andar (molliter ... pedes). Este ressurgimento da puella elegíaca em justaposição com a personificação do Amor elegíaco, de acordo com Maria Wyke, está a serviço da renovação de uma poesia amatória que aparentemente havia sido sepultada. ${ }^{87} \mathrm{O}$ corpo dessa mulher pode ser lido como a anatomia do texto elegíaco: Cíntia é a personificação da beleza, e a caracterização do seu andar suave (mollis) sugere tanto a leveza da poesia erótica como o movimento suave do pé métrico elegíaco.

As características do puer Amor na elegia 2.12, por sua vez, também coincidem com os motivos tópicos do amor elegíaco. ${ }^{88}$ Como menino $\left(\right.$ puer $\left.^{89}\right)$, ele simboliza a insensatez: os amantes assimilam esse aspecto de seu caráter e vivem sem juízo (sine sensu), preocupando-se apenas com paixões fugazes (leues curae) em detrimento dos grandes bens (magna bona). O poeta, do mesmo modo, reflete o semblante do deus, levando em si a imagem pueril (puerilis imago). Ao assumir os traços de Amor, Propércio sugere que sua persona poética também é um retrato do caráter leve e jovial de sua poesia erótica.

As ventosae alae de Amor sugerem a instabilidade inerente às relações amorosas, volúveis como o vento que se agita com o bater das asas do deus..$^{90}$ Por outro lado, as asas ligeiras podem referenciar aspectos da métrica elegíaca como metáfora para a rapidez do dístico elegíaco, que, atenuado em relação ao hexâmetro datílico pela supressão de um pé métrico no segundo verso, atribui um ritmo mais ágil e ligeiro ao texto. As asas também podem referenciar aspectos da matéria elegíaca: Wyke sugere que a perda das asas (perdidit pennas) pode indicar que Propércio pretende persistir com a poesia erótica pelos próximos poemas, uma vez que o deus recusa-se a abandonar o poeta. ${ }^{91}$ Por fim, o adjetivo ventosa (assim como levis) evoca a leveza e a brevidade calimaqueanas das elegias eróticas de Propércio.

A descrição das armas enfatiza as habilidades bélicas de Amor. ${ }^{92}$ A aljava é originária de Gnosso (pharetra Cnosia), principal cidade da ilha de Creta, famosa por seus hábeis arqueiros desde Homero. ${ }^{93}$ Fedeli indica que a

\footnotetext{
${ }^{86}$ Martins (2013).

${ }^{87}$ Wyke $(2002,67)$.

${ }^{88}$ Fedeli 2005, 343 e 347-8.

${ }^{89}$ Sobre a caracterização de Cupido como puer, cf. Serignolli (2013, 80-97).

${ }^{90}$ Sobre as asas de Eros, cf. Elinger (1953), Laurens (1988), Klein (2008), Serignolli (2013, 43).

${ }^{91}$ Wyke $(2002,67)$.

${ }_{92}$ Sobre as armas de Eros: Serignolli (2013, 44-6); Agnolon (2016).

${ }^{93}$ Hom., Il. 2.10.266; 23.850-ss.
} 
posição da aljava (ex umero ... utroque iacet) tem precedente no Eros Fugitivo de Mosco. ${ }^{94} \mathrm{O}$ uso do plural (nos ombros), por sua vez, lembra a caracterização de Apolo na passagem da Ilíada de Homero, em que o deus, portando a aljava nos ombros, manifesta de maneira veemente sua ira contra os Aqueus. ${ }^{95}$

As setas são farpadas (hamatae sagittae ${ }^{96}$ ). No jargão bélico, hamata remete ao formato agudo e penetrante das pontas das flechas envenenadas dos ferozes e temíveis arqueiros Citas e Partas. ${ }^{97}$ Por outro lado, a flecha, com seu formato fálico, é uma das principais e mais imediatas fontes de metáforas sexuais nos textos antigos. ${ }^{98}$ Os termos sagitta e tela são mencionados reiteradamente no poema (vv. 9, 13 e 18) e, com sua polissemia, atribuem ao poema um tom jocoso - o iocus ou diversão - que caracteriza uma das principais tópicas da elegia Augustana, a militia amoris (o paradoxo do amor como guerra), uma paródia da épica. ${ }^{99}$ Portanto, as armas de Cupido são um lembrete de sua crueldade e de sua habilidade como arqueiro (comparável até mesmo a Apolo, o deus arqueiro por excelência ${ }^{100}$ ) e ao mesmo tempo evocam o divertimento e o riso, sintetizando o paradoxo que combina o humor e a dureza da tópica militia amoris.

$\mathrm{O}$ veneno das setas, ao penetrar no corpo, além de causar uma ferida incurável (nec quisquam ex illo vulnere sanus abit), também impulsiona o poeta a escrever elegias eróticas. Como sugere Fedeli, os dois dísticos conclusivos da elegia 2.12 são um "prelúdio do renascimento do amor": com havíamos visto anteriormente, o poeta-amator chega à exaustão no embate contra o deus, mas não renuncia ao amor à puella elegíaca, implorando pela vida, para que possa seguir cantando sobre a beleza da mulher amada. ${ }^{101}$

Na elegia 2.13, o deus arqueiro reaparece no papel de inimigo implacável, sendo comparado a um feroz guerreiro Aquemênida, que habilmente atinge o poeta com suas incontáveis flechas e ordena que ele siga com Cíntia para o bosque de Ascra (lugar das Musas hesiódicas), indicando o movimento em direção a um gênero mais elevado:

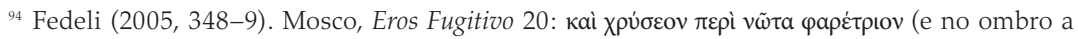
aljava de ouro). Cf. Mosco 1952.

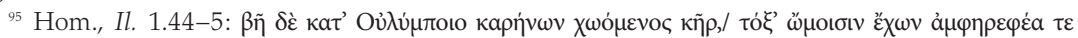

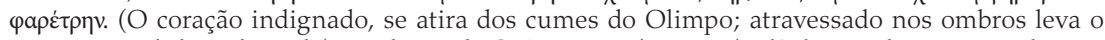
arco e o carcás bem-lavrado). Tradução de C. A. Nunes (2009, 59). Ilíada. Rio de Janeiro: Ediouro.

${ }_{96}^{6}$ Também hamata tela, em Ov., Am. 2.9.13; quid iuvat in nudis hamata retundere tela/ ossibus? ossa mihi nuda relinquit amor.

${ }^{97}$ Fedeli $(2005,348)$.

${ }_{98}$ Adams $(2002,19)$.

99 Sobre tópica a militia amoris, cf. Serignolli (2011).

${ }^{100}$ Cf. Serignolli $(2013,164-9)$ sobre a disputa entre Cupido e Apolo pela supremacia no arco e flechas em Ov., Met. 1.452-80.

${ }^{101}$ Fedeli $(2005,342)$. 
Non tot Achaemeniis armantur Susa sagittis, spicula quot nostro pectore fixit Amor. hic me tam gracilis vetuit contemnere Musas, iussit et Ascraeum sic habitare nemus,

2.13.5 non ut Pieriae quercus mea verba sequantur, aut possim Ismaria ducere valle feras, sed magis ut nostro stupefiat Cynthia versu: tunc ego sim Inachio notior arte Lino. ${ }^{102}$

Nem mesmo Susa está armado com tantas setas Aquemênidas quantas Amor cravou em meu peito. Ele proibiu que eu contrariasse as graciosas Musas, e ordenou que eu habitasse neste bosque de Ascra. Não espero que os carvalhos piérios sigam as minhas palavras, ou que eu possa conduzir as feras pelo vale Ismário, mas, para mim, mais vale que Cíntia encante-se com os meus versos: com esta arte eu ficaria mais famoso do que Lino de Argos.

Sob o jugo de Amor, Propércio pretende garantir sua imortalidade com os versos dedicados a Cíntia.

Por fim, na elegia 2.34, Propércio encerra o programa poético dos Livros 1 e 2, triunfando com sua elegia erótica. Considerando uma divisão deste poema em três seções, ${ }^{103}$ podemos resumi-las em: (1) Linceu, destinatário do poema, apaixona-se por Cíntia e é censurado pelo seu comportamento ${ }^{104}$; (2) Linceu apaixona-se por outra, e Propércio, como praeceptor amoris, o ensina sobre a nova poesia ${ }^{105}$; (3) Propércio procura legitimar o valor de sua obra (comparando-a com a de Virgílio) e elevar sua persona poética, incluindo-se em uma genealogia de poetas. ${ }^{106}$ Amor aparece no início de cada uma dessas seções, sendo identificado: (1) por suas ações: Amor, "aquele deus" que destrói amizades e promove guerras; (2) pelas afecções que causa: o "nosso deus" que desperta a insânia; e (3) por sua imago e pelo ambiente em que se manifesta: o deus arqueiro de mira inequívoca que atua durante os simpósios.

Inicialmente, Propércio, como praeceptor amoris, questiona os perigos de confiar a amada a Amor:

Cur quisquam faciem dominae iam credat Amori?

sic erepta mihi paene puella meast. expertus dico, nemost in amore fidelis:

2.34 .5 formosam raro non sibi quisque petit. polluit ille deus cognatos, solvit amicos,

${ }^{102}$ Prop., 2.13.1-8.

${ }^{103}$ Sobre a divisão deste poema, cf. Stahl 1985,187-8; Heyworth 2007, 264-80; Fedelli 2005, 952.

${ }^{104}$ Prop. 2.34.1-24.

${ }^{105}$ Prop. 2.34.25-58.

${ }^{106}$ Comparação com a obra de Virgílio, Prop. 2.34.59-80. Genealogia de poetas, Prop. 2.34.8194; cf. também Ovídio Tr. 4.10.53-4. 
et bene concordis tristia ad arma vocat.

hospes in hospitium Menelao venit adulter;

Colchis et ignotum nempe secuta virum. ${ }^{107}$

Porque alguém confiaria a face da sua amada a Amor? Assim minha amada quase me foi roubada. Como perito afirmo: ninguém é fiel no amor, uma face formosa não raro desperta a cobiça.

2.34.5 Aquele deus desonra as famílias, destrói as amizades e incita às armas os que vivem em plena concórdia. Como hóspede, um adúltero foi recebido por Menelau, e a mulher da Cólquida, sem dúvida, seguiu um homem desconhecido.

Propércio atribui a Amor a responsabilidade por causar uma guerra como a de Tróia. ${ }^{108}$ Na Ilíada de Homero, Páris (o adúltero por excelência) e Helena são vítimas dos ardis de Vênus. ${ }^{109}$ Embora Cupido não seja mencionado na Ilíada como executor dos desígnios de Vênus na trama que envolve Páris e Helena, em pinturas parietais de Pompeia esse parece ser um lugar comum, como podemos observar na Figura 1. Posicionado diante de uma porta entreaberta, em um nicho entre duas colunas, Cupido entrepõe-se entre os amantes. Ele olha para Helena enquanto indica Páris. Como vimos, nos versos de Propércio, Cupido, o inseparável filho da deusa do amor, também é apontado como causador de um amor que gera guerras. ${ }^{110}$ Desse modo, Propércio, como poeta-amante, em suas elegias, pode ser comparado a Páris como uma vítima de Cupido. E Cíntia pode ser comparada a Helena, a mais bela entre as mulheres, cujo amor pelo príncipe troiano foi o estopim da guerra de Troia. ${ }^{111}$

Na segunda parte da elegia 2.34, ${ }^{112}$ Amor é identificado pelos efeitos que causa em Linceu, especialmente a insânia. Linceu é aconselhado a mudar os temas de suas poesias e buscar outros paradigmas:

2.34 .30

Lynceus ipse meus seros insanit amores!

serum te nostros laetor adire deos.

quid tua Socraticis tibi nunc sapientia libris

proderit aut rerum dicere posse vias?

aut quid Cretaei tibi prosunt carmina plectri?

nil iuvat in magno vester amore senex.

tu satius Musis leviorem imitere Philitan

et non inflati somnia Callimachi. ${ }^{113}$

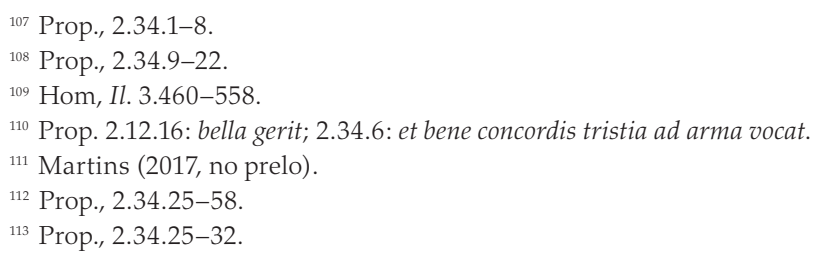




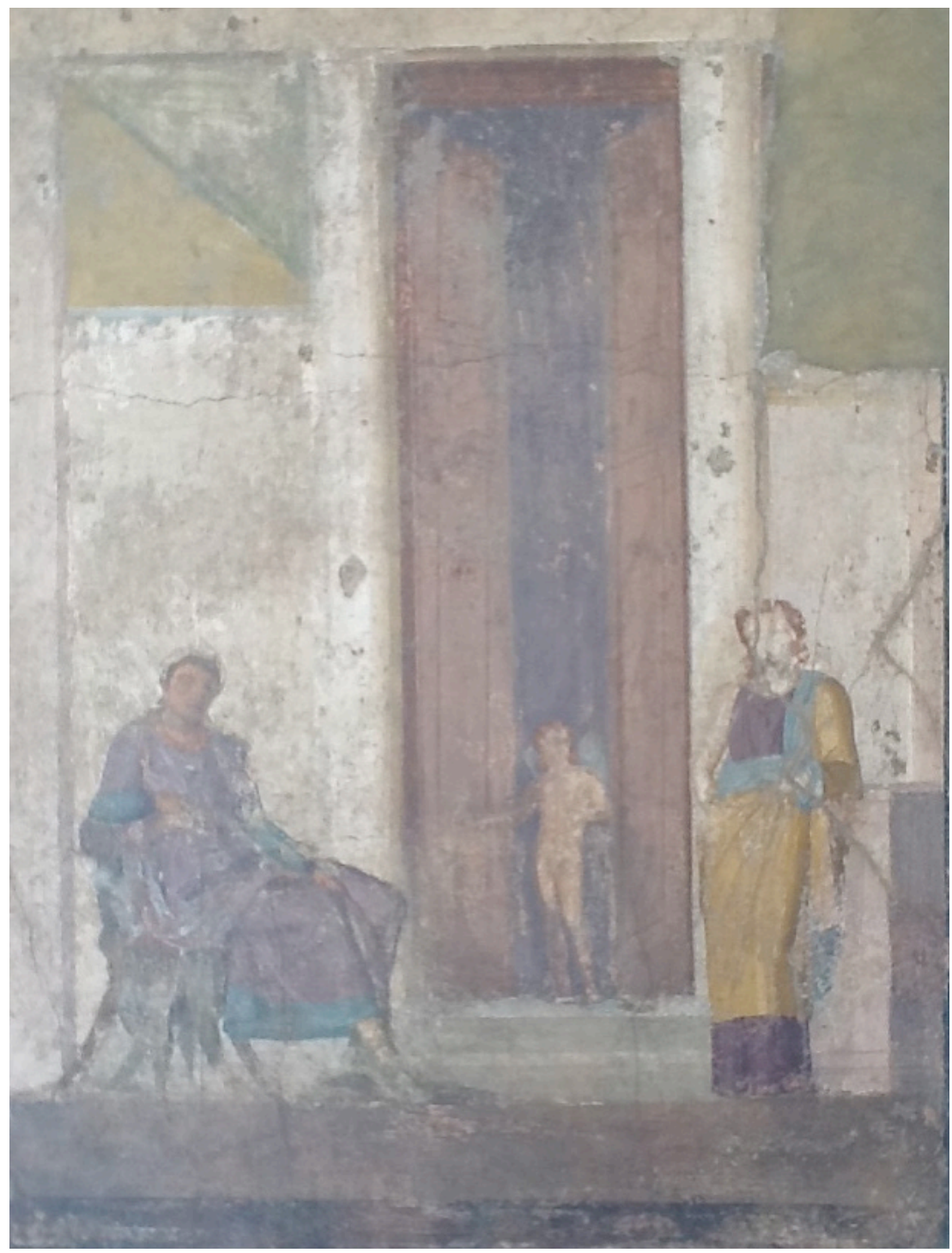

Figura 1. Cupido entre Páris e Helena.

Museo Archeologico Nazionale di Napoli, Nápoles, Itália.

Inv.: 114320. Pompeia. Casa de Jasão, IX 5, 18, cubículo (e).

Alt.: 101 cm. Larg.: 130 cm. Datação: 20-25 d.C.

Cf. Sampaolo, Bragantini (2009, 238).

Foto: Lya Serignolli. 
Até meu amigo Linceu está louco com amores tardios! Alegro-me que tu, ainda que tarde, recorras aos nossos deuses! De que te valerá agora a sabedoria dos livros socráticos, ou poder explicar as leis do universo? De que te servem os cantos da lira cretense? Vosso ancião nada ajuda em um grande amor. É melhor que tu imites a Musa mais leve de Filetas e o sonho não inflado de Calímaco.

Fedeli observa que o verso 25 é considerado por alguns autores como o início de outro poema, pois supõe-se que Linceu possua uma nova paixão. ${ }^{114}$ Assim como Propércio e Pôntico, Linceu é mais um poeta a ser ferido pelas setas de Amor, passando a sofrer o rá日oc imputado pelo deus. ${ }^{115} \mathrm{~A}$ diferença entre Propércio e seus amigos é que ele próprio foi ferido por Amor enquanto jovem e inexperiente, ${ }^{116}$ ao passo que Linceu e Pôntico são poetas experientes em outro gênero de poesia, e por isso sofrerão ainda mais para aprenderem as lições. ${ }^{117}$

Como sugere Fedeli, Linceu não é simplesmente um rival no amor, mas um poeta maduro que cultiva a poesia elevada e a filosofia moral e que trata tudo com pompa e solenidade. ${ }^{118}$ Com a adesão a esse novo modo de vida sob os auspícios de Amor, o poeta severo empresta sua auctoritas à poesia erótica de Propércio. Como rei entre os jovens no simpósio, Propércio ensina a Linceu as lições que aprendeu com Amor sobre como escrever poesia, e aconselha o amigo a adequar sua poesia, insistindo para que ele abandone os temas sérios e elevados de Ésquilo, Antímaco e Homero e comece a imitar os versos suaves e breves de Calímaco e Filetas.

Propércio encerra a segunda parte do poema evidenciando a si próprio como um modelo. Ele constrói sua persona nos moldes de Horácio nas Odes, como um poeta de origem humilde, sem fortuna e sem triunfos passados, que é elevado à glória e à fama por seus engenhosos versos. ${ }^{119}$ Assim, apesar de desprovido de fortunas ancestrais, ele atinge a glória rodeado de mulheres no simpósio regado a vinho:

\footnotetext{
${ }^{114}$ Fedeli $(2005,964)$.

${ }^{115}$ Para Stahl $(1985,177)$, Linceu é "outro Pôntico, porém com teor mais dramático". Ambos são poetas severos vitimados pelo Amor tardio (serus Amor: Prop., 1.7.20, 2.34.25), que foram tomados pela insânia (insanus, 1.9.16 = 2.34.25), e cujo modo de produzir poesia modificou-se sob a ação do suave deus (note o uso de mollis aplicado à poesia em 1.7.19 = 2.34.42).

${ }^{116}$ Prop., 1.1.1-4.

${ }^{117}$ Para menções a Pôntico, cf. Prop., 1.7 e 1.9.

${ }_{118}$ Fedelli $(2005,952)$.

${ }^{119}$ Cf. Hor., C. 3.30. Fedelli $(2005,987)$ : a referência à origem modesta, acompanhada da reivindicação de um presente enobrecedor próxima da conclusão do livro, aproxima Propércio da técnica de Horácio que contrapõe a modéstia da sua condição a um presente de grande notoriedade na conclusão do terceiro livro das Odes.
} 
aspice me, cui parva domi fortuna relictast

nullus et antiquo Marte triumphus avi,

ut regnem mixtas inter conviva puellas

hoc ego, quo tibi nunc elevor, ingenio! ${ }^{120}$

Olha para mim, cuja herança é pequena e desprovida de triunfos de ancestrais em antigas batalhas, e veja que agora reino em banquetes em meio a um bando de mulheres, graças a esse engenho pelo qual me desprezas!

No início da terceira seção da elegia 2.34, Cupido é identificado como um deus arqueiro de mira inequívoca, que atinge Propércio com suas setas no simpósio ${ }^{121}$ :

mi libet hesternis posito languere corollis, quem tetigit iactu certus ad ossa deus ${ }^{122}$

me agrada deitar sobre as guirlandas da véspera, a mim, a quem o certeiro deus feriu até os ossos com seus dardos.

É nesse ambiente, o simpósio, que Propércio proclama ter atingido a glória como poeta. Depois de ser coroado no simpósio, Propércio dedica um encômio de 15 versos à obra de Virgílio, que não é modulada por Amor, mas pelo "Cíntio deus". ${ }^{123} \mathrm{O}$ nome Cíntia, não ao acaso, lembra o epíteto de Apolo - Cíntio - aludindo ao caráter também apolíneo da poesia erótica de Propércio. Segundo Fedeli, o elogio do Virgílio épico insere-se no esquema das recusationes, em que o poeta, cortesmente, confirma seu desinteresse pela poesia épica e indica alguém que, mais corajoso que ele, é capaz de fazê-lo em seu lugar. ${ }^{124}$ Sob os auspícios de diferentes deuses, cada poeta é o melhor no gênero que pratica: Propércio com sua poesia erótica sob os auspícios de Amor equipara-se a Virgílio com sua épica apolínea, e também alcançará a fama com seus versos.

Ao longo dos Livros 1 e 2, Propércio aprendeu e ensinou as duras lições de Amor e, por fim, foi coroado no simpósio por sua poesia erótica de louvores à Cíntia, a garantia de sua fama e glória. Nos últimos versos da elegia de encerramento do Livro 2, Propércio, com sua poesia dedicada a Cíntia, inclui-se em um catálogo de poetas que, em algum momento, escreveram versos de amor a uma única mulher: Varrão para Leucádia, Catulo

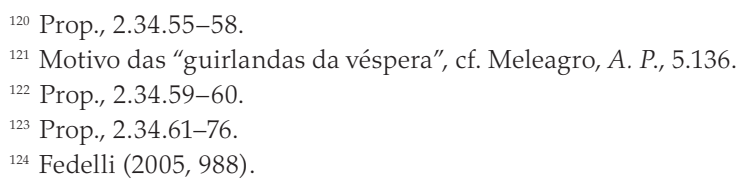


para Lésbia, Calvo para Quintília e Galo para Licóris. ${ }^{125}$ Os atributos desses poetas coincidem com os principais loci encontrados em elegias eróticas de Propércio: de Varrão o ludus e o ardor, de Catulo a lascívia e a fama, de Calvo a erudição e o lamento; e de Galo o amor e a ferida.

Após o êxito obtido com sua poesia erótica, Propércio transita para outro programa poético, em que a relação com Cíntia não é o tema principal, ao mesmo tempo em que Amor perde a soberania e o status de divindade tutelar da poesia dos livros anteriores. Propércio inicia a elegia 3.1 inserindo-se como personagem central de uma cena de triunfo no bosque sagrado de Calímaco e Filetas:

Callimachi Manes et Coi sacra Philitae, in vestrum, quaeso, me sinite ire nemus. primus ego ingredior puro de fonte sacerdos Itala per Graios orgia ferre choros. ${ }^{126}$

Manes de Calímaco e ritos sagrados de Filetas de Cós, peço-vos, permiti-me entrar em vosso bosque. Sacerdote, vindo da fonte purificado, eu sou o primeiro a entrar trazendo mistérios itálicos em danças gregas.

Enquanto a imagem do poeta é amplificada, a de Amor é diminuída: Propércio, antes condenado ao seruitium amoris, agora aparece triunfante, recebendo as mais altas honrarias, ao passo que Amor, antes deus supremo de sua poesia, ${ }^{127}$ surge como parui Amores, que desfilam ao lado do poeta como se fossem os pueri de César na carruagem principal. Nessa versão diminuta e pluralizada, Amor faz sua última aparição ao lado de Propércio ${ }^{128}$ :

dicite, quo pariter carmen tenuastis in antro quove pede ingressi? quamve bibistis aquam? ah valeat, Phoebum quicumque moratur in armis! exactus tenui pumice versus eat, quo me Fama levat terra sublimis, et a me nata coronatis Musa triumphat equis, et mecum in curru parvi vectantur Amores, scriptorumque meas turba secuta rotas. quid frustra immissis mecum certatis habenis? non datur ad Musas currere lata via. ${ }^{129}$

${ }^{125}$ Prop., 2.34.85-94.

${ }^{126}$ Prop., 3.1.1-4.

${ }^{127}$ Recordemos o que diz Propércio na elegia 2.8.39-40: inferior multo cum sim vel matre vel armis, mirum, si de me iure triumphat Amor? Uma vez que sou muito inferior a Amor em mãe e em armas, por que se admirar que ele naturalmente triunfe sobre mim?

${ }^{128}$ Sobre a forma pluralizada dos Amores cf. Serignolli $(2013,53-68,91-7)$.

${ }^{129}$ Prop., 3.1.5-14. 
Dizei-me, em que gruta igualmente atenuastes o canto? E com que pé entrastes? E de que água bebestes? Ah, longe daqui quem quer que detenha Febo em armas! Que meu verso prossiga, burilado com suave pedra-pomes, pelo qual a Fama sublime eleva-me da terra, e a Musa nascida de mim triunfa com cavalos coroados. Comigo, no carro, os pequenos Amores são conduzidos e a turba de escritores segue minhas rodas. Por que, afrouxadas as rédeas, em vão, disputas comigo? Não é dado às Musas correr em larga via.

Nos livros 3 e 4, outras divindades como Apolo, Calíope e Baco substituem Amor como patronos da poesia. A temática erótica, assume novas tonalidades e deixa de ser central como nos livros anteriores, dando maior espaço a temas didáticos, épicos, etiológicos e iâmbicos.

\section{CONCLUSÃO}

Observando o tratamento retórico e poético dado à forma e às ações de Amor na elegia 2.12, procurei demonstrar de que modo a construção da imagem do deus pode evidenciar aspectos de um programa poético em que se incluem as elegias eróticas dos Livros 1 e 2 de Propércio. Vimos que esta elegia - que coloca em destaque a paradoxal figura de Cupido como divindade tutelar da poesia e veiculador da paixão erótica - associa-se a outros poemas, tendo em vista a relação de interdependência entre puer Amor e puella elegíaca: Amor, como guardião de Cíntia, é a garantia de que ela irá se manter como tema principal dos dois primeiros livros de Propércio. Considerando-se os possíveis antecedentes da elegia 2.12, e o uso das tópicas em uma estrutura argumentativa que lembra um exercício retórico, percebe-se que a ligação com a poesia epigramática helenística atribui vivacidade à descrição de Eros, enquanto os lugares-comuns da comédia acrescentam humor à argumentação. Os argumentos usados nesta elegia mostram que Amor não é apenas o veiculador de afecções veementes que geram uma guerra (militia amoris), motivando o lamento elegíaco, mas é também a força que move o poeta a escrever versos em louvor a Cíntia, justificando, assim, a sua escolha pela poesia erótica. 


\section{REFERÊNCIAS}

Adams, J. N. (2002). The Latin Sexual Vocabulary. London: Duckworth.

Agnolon, A. (2016). "Hic ego dux milesque bonus: As Armas de Eros na Elegia Romana". Nuntius Antiquus 12(1): 117-30.

Amaral, F. V. (2009) A guilanda de sua Guirlanda. Epigramas de Meleagro de Gádara: tradução e estudo. Dissertação de Mestrado apresentada ao Programa PósGraduação em Letras Clássicas do DLCV da USP.

Ateneu (1939). Deipnosofistas. Cf.: S. P. Peppink, ed.. Athenaeus Soph., Deipnosophistae (epitome). Athenaei dipnosophistarum epitome, vol. 2,2. Leiden: Brill. C. D. Yonge (1854). Athenaeus of Naucratis. The Deipnosophists, or, Banquet of the learned of Athenæus. Volume III, Book XIII, 13. Literally translated by C. D. Yonge. London: Bohn's Classical Library.

Bing, P.; Bruss, J. S., ed. (2007). Brill's Companion to Helenistic Epigram. Leiden, Boston: Brill.

Cairns, F. (2010). Generic Composition in Greek and Roman Poetry. Ann Arbor: Michigan Classical Press.

Calame, C. (1999). The poetics of Eros in Ancient Greece. New Jersey: Princeton University Press.

Carson, A. (2009). Eros the bittersweet. Princeton: Princeton University Press.

Chin, C. (2005). "Statius Silv. 4.6 and the Epigramatic Origins of Ekphrasis". TCJ $100(3): 247-63$.

Cicero (1949). De Inventione. De optimo genere oratorum. Topica. With an English translation by H.M. Hubbell. Cambridge: Harvard University Press.

Elinger, I. E. (1953). Winged figures. Studies Presented to David Moore Robinson on this Seventieth Birthday. Volume II. Saint Louis: Washington University.

Elsner, J. (2007). "Eight ways of looking at an Ekphrasis". CPh, Vol. 102, n. 1, Special Issues on Ekphrasis, pp. i-vi.

Enk, P. J. (1929). "Lucubrationes Propertianae". Mnemosyne, New Series, vol. 57, Pars 2, pp. 145-59.

Garrison, D. (1978). Mild Frenzy. A Reading of the Hellenistic Love Epigram. [Hermes Einzelschriften 41]. Wiesbaden: Steiner.

Graver, M. (2002). Cicero on the Emotions. Tusculan Disputations 3 and 4. Chicago: University of Chicago Press.

Gunter, H. C. ed. (2006). Brill's Companion to Propertius. Leiden, Boston: Koninklijke Brill NV.

Gutzwiller, K. J. (2007). “The Paradox of Amatory Epigram”. In: P. Bing; J. S. Bruss, ed.. Brill's Companion to Helenistic Epigram. Leiden, Boston: Brill.

Kennedy, G. (2003). Progymnasmata: Greek textbooks of prose composition and rhetoric. Translated with introductions and notes by George A. Kennedy. Atlanta: Society of Biblical Literature.

Klein, F. (2008). “Les Ailes Perdues et Retrouvées du dieu Amour: la définition généric de l'elégie chez Properce et Ovide". Latomus 67(3):662-78.

Lang, C. 1881. Cornuti Theologiae Graecae Compendium 25. Leipzig: Teubner.

Laurens, P. (1988). "Éros Apteros ou la description impertinente." Revue des Études Grecques 101(482-4):253-74. Paris: Les Belles Letres. 
Long, T. (1978). "Two Unnoticed Parallels to Propertius 2.12". CPh 73(2):141-2.

Lyne, R.O.A.M. (1998). "Propertius 2.10 and 11 and the Structure of Books '2a' and '2b'." JRS 88:21-36.

Mannlein-Robert, I. (2007). "Epigrams on Art. Voice and Voicellesness in Ecphrastic Epigram. In: P. Bing, J. S. Bruss (ed). Brill's Companion to Hellenistic Epigram. Leiden: Brill.

Martins, P. (2009). Elegia Romana - Construção e Efeito. São Paulo: Humanitas.

Martins, P. (2013). Pictura Loquens, Poesis Tacens. Limites da Representação. Tese (Livre Docência). Universidade de São Paulo, Faculdade de Filosofia, Letras e Ciências Humanas.

Martins, P. (2016). "Espelhamento Metapoético: Propércio 1.2 e 2.1". Organon 31(60):205-27. Porto Alegre: Universidade Federal do Rio Grande do Sul.

Martins, P. (2017). “Tum Longas Condimus Iliadas: A Helena de Propércio." In: Revista Archai: Revista de Estudos sobre as Origens do Pensamento Ocidental. Brasília: Universidade de Brasília. (no prelo).

Miller, P. A. (2002). Latin Erotic Elegy. An anthology and reader. New York: Routledge.

Miller, P. A. (2004). Subjecting Verses. Latin Love Elegy and the Emergence of the Real. Princeton: Princeton University Press.

Mosco. 1952. "Eros Drapeta." In Bucolici Graeci, edited by A. S. F. Gow. Oxford: Clarendon Press.

Murgia, C. E. (2000). The Division of Propertius 2, MD, 45, 147-252.

Nock, A. D. (1929). "Propertius II.12". CR 43(4):126-7.

Pichon, R. (1991) "De Sermone amatorio apud Latinos elegiarum scriptores". In Index Verborum Amatoriorum, 75-303. Georg Olms Verlag: Hildesheim, Zurich, New York.

Propércio (2005). Properzio Elegie Libro II. Introduzione, Testo e Commento P. Fedeli. Cambridge: Francis Cairns Publications.

Propércio (2006). Elegies. Edited and Translated by G. P. Goold. Cambridge: Harvard University Press.

Propércio (1977). Propertius. Elegies I-IV. Edited with introduction and commentary by L. Richardson Jr.. Norman: University of Oklahoma Press.

Propércio (1996). The Elegies of Propertius. Edited with introduction and commentary by H. E. Butler and E. A. Barber. Hildesheim: Georg Olms Verlag.

Propércio (1990). Propertius: Elegies. G. P. Goold (ed.). Cambridge: Harvard University Press.

Propércio (1816). Sexti Aurelii Propertii Carmina. K. Lachman, (ed.). Leipzig: Gerhard Fleischer.

Quintiliano (1996). Institutio Oratoria. Books I-III. With an English Translation by H. E. Butler. Cambridge: Harvard University Press.

Quintiliano (2006). Institutio Oratoria. Book 2. Edited by Tobias Reinhardt and Michael Wointerbottom. Oxford: Oxford University Press.

Quintiliano (1987). Quintilian on the Teaching of Speaking and Writing. Translations from Books One, Two, and Ten of the Institutio Oratoria. Edited by James J. Murphy. Carbondale: Southern Illinois University Press.

Ragusa, G. (2008). Imagens de Afrodite: Variações sobre a Deusa na Mélica Grega Arcaica. Tese de doutorado. São Paulo: Universidade de São Paulo. 
Ragusa, G. (2005). Fragmentos de uma deusa: a representação de Afrodite na lírica de Safo. Campinas, SP: Editora da UNICAMP.

Sánchez, M. B. (1986). Bucolicos Griegos. Tres Cantos: Akai Ediciones.

Sampaolo, V.; Bragantini, I. (2009). La Pittura Pompeiana. Napoli: Electa.

Serignolli, L. (2011). "Militia Amoris: Uma Figura do Amor" In Coleção de Estudos Clássicos 2, 221-9. Rio de Janeiro: 7 Letras.

Serignolli, L. (2013). Imagines Amoris. As Figurações de Amor do Final da República ao Período Augustano. Dissertação de Mestrado. DLCV-FFLCH, Universidade de São Paulo.

The Greek Bucolic Poets (1919). With an English translation by J. M. Edmonds. London: William Heinemann.

The Greek Anthology I. Books 1-6 (1993). Translated by W. R. Paton. Cambridge: Harvard University Press. The Greek Anthology IV. Books 10-12 (1979). Translated by W. R. Paton. Cambridge: Harvard University Press.

Webb, R. (1997). "Imagination and the arousal of the emotions in Greco-Roman rhetoric". In: S. M. Braund and C. Gill, ed.. The Passions in Roman Thought and Literature. Cambridge: Cambridge University Press.

Webb, R. (2009). Ekphrasis, Imagination and Persuasion in Ancient Rhetorical Theory and Practice. Farnham: Ashgate Publishing Limited.

Wyke, M. (1987). “Written Women: Propertius' Scripta Puella." JRS 77:47-61.

Wyke, M. (2002). The Roman Mistress. Ancient and Modern Representations. Oxford: Oxford University Press.

Zanker, G. (2004). Modes of Viewing in Hellenistic Poetry and Art. Madison: The University of Wisconsin Press.

Title. A painting of the god of Love: poetics and rhetoric in Propertius 2.12

Abstract. In Propertius elegy 2.12, the god of Love is presented as the admirable work of a painter and as vehicle of erotic passion. In this poem, erotic passion is compared to a war caused by the god (militia amoris), motivating, on the hand, the lament (which is one of distinguishing features of the elegiac genre), and, on the other, triggering in the poet the desire to write verses that please the god. In this article, my aim is to observe rhetorical and poetic aspects of elegy 2.12, considering the treatment of the form and actions of Love personified. First, I will investigate possible antecedents of this elegy, looking at the choice of the commonplaces used in the construction of the image of the god. Secondly, I will observe aspects of the erotic rá $\theta$ oc as both a rhetorical artifice and poetic impulse. Finally, I will examine the connections between elegy 2.12 and other elegies of Propertius' Books 1 and 2, with focus on the relationship of interdependency between the representations of the puer Amor as patron of poetry and of the elegiac puella (Cynthia) as object of Propertius' elegies. Therefore, I will try to demonstrate how the characteristics of Love in elegy 2.12 may function as markers of a poetic programme that includes the erotic elegies of Propertius' Books 1 and 2.

Keywords. Love; Cupid; Eros; Propertius; image; poetics; rhetoric. 